\title{
Elbasvir/Grazoprevir Experience - A New Glance at HCV Treatment: Case Report
}

\author{
HCV Tedavisinde Yeni Bir Bakıș Elbasvir/Grazoprevir Deneyimi: Olgu Sunumu
}

\author{
Mustafa Kemal ÇELEN1', Irem AKDEMIR², Recep TEKIN¹, Kadim BAYAN³, Celal AYAZ1 \\ ${ }^{1}$ Dicle University Faculty of Medicine, Department of Infectious Diseases, Diyarbakır, Turkey \\ 2Batman Regional Public Hospital, Clinic of Infectious Diseases, Batman, Turkey \\ 3 Private Sultan Hospital, Clinic of Gastroenterology, Diyarbakır, Turkey
}

\begin{abstract}
Hepatitis C is a viral disease having a worldwide importance and posing a risk for liver complications. With the new treatment options, it is easy to manage with higher rates of success. Among them, one of the most recent one is elbasvir/grazoprevir option. This study presents the results of two treatment-naive patients treated with elbasvir/grazoprevir. The first case was a male non-cirrhotic patient and the second one was a female who suffered from compensated hepatic cirrhosis. Both patients received elbasvir/grazoprevir 50/100 $\mathrm{mg}$ in a single tablet for 12 weeks. Persistent viral response was achieved in both patients and no side effect was observed during the treatment. Elbasvir/grazoprevir combination, one of the recent treatments, was considered effective and tolerable.

Keywords: Hepatitis C virus, oral antiviral treatment, elbasvir/ grazoprevir
\end{abstract}

\section{ÖZ}

Hepatit C dünya genelinde önemini sürdüren ve karaciğer komplikasyonları açısından da hala risk oluşturan bir viral hastalıktır. Yeni tedavi seçenekleri ile yöntemi daha kolay ve başarısı daha yüksektir. Bunlar içersinden en yenilerden biri de elbasvir/grazoprevir seçeneğidir. Bu çalışmada elbasvir/grazoprevir tedavisi alan iki hastamıza ait sonuçlar paylaşıldı. Iki olgunun değerlendirildiği bu çalışmada olgularımızdan ikisi de tedavi deneyimsiz olup; birinci olgu non-sirotik erkek hasta diğeri ise kompanse karaciğer sirozu olan kadın hastadır. Her iki hasta 12 haftalık elbasvir/grazoprevir 50/100 mg tek doz tablet ile tedavi edildi. Her iki hastada da kalıcı viral yanıt elde edilirken ilaç kullanımı esnasında da herhangi bir yan etki izlenmedi. Yeni tedavi seçeneklerinden biri olan elbasvir/ grazoprevir kombinasyonu hem etkin hem de tolere edilebilir olarak değerlendirildi.

Anahtar Kelimeler: Hepatit C virüs, oral antiviral tedavi, elbasvir/ grazoprevir

Celen MK., Akdemir I, Tekin R, Bayan K, Ayaz C. Elbasvir/Grazoprevir Experience- A New Glance at HCV Treatment: Case Report. Viral Hepat J. 2017;23:34-36.

\section{Introduction}

Hepatitis $\mathrm{C}$ virus $(\mathrm{HCV})$ is a viral disease which still has a worldwide importance and poses a risk of liver complications. It is one of the major reasons for hepatic failure, cirrhosis and liver cancer. Conventional treatment using interferon-based drug regimens, which has been available for several years, was an option difficult to tolerate due to its low rate of treatment success and serious side effects. The first generation protease inhibitors, which have been involved in the treatment in the recent years, were among the options difficult to be used in terms of side effects. However, the new generation oral antivirals were introduced as a satisfactory treatment with better results and less side effects thanks to the option of single tablet with short-term treatments and no interferon content. Among them, one of the most recent one is elbasvir/grazoprevir combination $(1,2,3)$. This study presents the results of two patients treated with elbasvir/grazoprevir. The recommended dose of elbasvir/ grazoprevir combination is one tablet of $50 \mathrm{mg} / 100 \mathrm{mg}$ taken orally once daily $(4,5)$. 


\section{Case}

Grazoprevir, a NS3/4A protease inhibitor, and elbasvir, an NS5A inhibitor, have become in place in HCV treatment in the dose of $100 \mathrm{mg} /$ day and $50 \mathrm{mg} /$ day, respectively, combined in a single tablet with a recommended treatment duration of 12 weeks. Two patients were treated in our hospital with this treatment option. Elbasvir/grazoprevir is indicated for the treatment of patients with genotype 1, 4 and 6, cirrhotic and non-cirrhotic, both treatmentnaive and treatment-experienced ones.

\section{Case 1}

The first case was a 50-year-old male HCV-infected patient who has been followed up since 2003. The patient was diagnosed with diabetes mellitus (DM) in 2006. With a HCV-RNA level of $342.000 \mathrm{IU} / \mathrm{mL}$ at baseline, he was reported to have genotype 1B. No decompensation was observed and liver ultrasound was normal. The patient had no co-infection and did not drink alcohol. The patient was administrated elbasvir/grazoprevir combination starting with a single dose daily. The laboratory values at baseline and during the follow-up period are given in Table 1. The patient had negative HCV-RNA test in the first week. Persistent viral response was achieved at the end of the treatment which was tolerated well in terms of side effects although nausea, toothache and itching were observed. Persistent viral response was achieved with negative HCV-RNA test in the sixth month, at the end of the treatment. Tolerating the treatment with no significant adverse effect, the patient's compliance to treatment was found to be high.

\section{Case 2}

The second case was a treatment-naive 63-year-old female patient with compensated hepatic cirrhosis. She had refused interferon treatment for years, since she witnessed that a relative of her suffered from the side effects developed during the use of pegylated interferon. Diagnosed with DM in 2009, the patient has been followed up since 2005. With genotype 1B and a HCV-RNA load of $2.300 .000 \mathrm{IU} / \mathrm{mL}$, the patient had never received treatment. The patient suffered from hypertension and no co-infection. The patient was considered as Child-pugh A. She was administered elbasvir/grazoprevir combination in fixed dose. The details of the treatment process are given in Table 2. Persistent viral response was achieved with a negative HCV-RNA test in the sixth month, at the end of the treatment. She experienced no other significant side effects except for frequent urination, dizziness and nausea.

Table 1. Outset of treatment for the case 1 and values observed during the treatment

\begin{tabular}{|c|c|c|c|c|c|c|c|}
\hline & HCV-RNA & ALT/AST & HGB & PLT & INR & $\mathrm{AE}$ & SAE \\
\hline Screen & 342.000 & $41 / 35$ & 12.1 & 189.000 & 1.1 & - & - \\
\hline Visit-2 & 314.000 & $36 / 12$ & 11.7 & 200.000 & 1.1 & - & - \\
\hline Week 1 & 0 & $29 / 21$ & 11.8 & 213.000 & 1.05 & - & - \\
\hline Week 2 & 0 & $28 / 20$ & 12.0 & 256.000 & 1.1 & Nausea & - \\
\hline Week 4 & 0 & $27 / 21$ & 11.8 & 198.000 & 1.01 & - & - \\
\hline Week 6 & 0 & $28 / 23$ & 12.3 & 242.000 & 0.9 & - & - \\
\hline Week 8 & 0 & $34 / 29$ & 11.9 & 201.000 & 1.1 & Toothache & - \\
\hline Week 10 & 0 & $26 / 23$ & 12.8 & 230.000 & 1.1 & - & - \\
\hline Week 12 & 0 & $28 / 22$ & 11.8 & 221.000 & 1.05 & - & - \\
\hline Week 16 & 0 & $27 / 22$ & 11.7 & 187.000 & 1.1 & Itching & - \\
\hline Week 24 & 0 & $32 / 36$ & 12.1 & 209.000 & 1.03 & - & - \\
\hline
\end{tabular}

\begin{tabular}{|c|c|c|c|c|c|c|c|}
\hline & HCV-RNA & ALT/AST & HGB & PLT & INR & $\mathrm{AE}$ & SAE \\
\hline Screen & 2.300 .000 & $23 / 35$ & 13.1 & 109.000 & 1.3 & - & - \\
\hline Visit-2 & 2.415 .000 & $28 / 41$ & 12.3 & 110.000 & 1.34 & - & - \\
\hline Week 1 & 0 & $49 / 51$ & 12.8 & 103.000 & 1.35 & Dizziness & - \\
\hline Week 2 & 0 & $38 / 50$ & 13.0 & 96.000 & 1.23 & Nausea & - \\
\hline Week 4 & 0 & $24 / 41$ & 12.8 & 98.000 & 1.09 & - & - \\
\hline Week 6 & 0 & $22 / 33$ & 13.3 & 102.000 & 1.19 & - & - \\
\hline Week 8 & 0 & $34 / 39$ & 13.9 & 101.000 & 1.19 & - & - \\
\hline Week 10 & 0 & $36 / 43$ & 12.8 & 130.000 & 1.27 & Pollakiuria & - \\
\hline Week 12 & 0 & $38 / 52$ & 12.8 & 121.000 & 1.10 & - & - \\
\hline Week 16 & 0 & $37 / 42$ & 13.7 & 107.000 & 1.23 & Pollakiuria & - \\
\hline Week 24 & 0 & $32 / 36$ & 13.1 & 109.000 & 1.20 & - & - \\
\hline
\end{tabular}




\section{Discussion}

Grazoprevir, NS3/4A protease inhibitor, and elbasvir, NS5A inhibitor, have taken place in $\mathrm{HCV}$ treatment with the recommended dose of elbasvir/grazoprevir combination of $50 \mathrm{mg} / 100 \mathrm{mg}$ taken orally once daily for 12 weeks. It is effective in patients with genotype 1, 4 and 6, regardless of being treatment-naive or treatment-experienced, with a persistent viral response of up to $100 \%$.

In a clinical study of phase 3 in which both treatmentnaive and treatment-experienced HCV patients were involved, elbasvir/grazoprevir combination was compared with sofosbuvir plus pegylated interferon alpha. In this study including a total 257 patients, the treatment was administered for 12 weeks. The rate of sustained viral response was found to be $99.2 \%$ for elbasvir/grazoprevir, while it was $90.5 \%$ for sofosbuvir with pegylated interferon alpha. In patients in the group of sofosbuvir and pegylated interferon alpha combination, the frequency of adverse effects and non-compliance with treatment were higher than in elbasvir/grazoprevir combination (4). Compliance with the treatment was high in both of our cases and no significant side effects were reported.

\section{Conclusion}

$\mathrm{HCV}$ is a viral disease which still has a worldwide important posing a risk for liver complications. It is one of the major reasons for hepatic failure, cirrhosis and liver cancer. Elbasvir/grazoprevir single dose regimen is a new drug with a high sustained virological response at chronic HCV patients.

\section{Ethics}

Informed Consent: A consent form was completed by all participants.
Peer-review: Internally peer-reviewed.

\section{Authorship Contributions}

Concept: C.A., Design: I.A., Analysis or Interpretation: R.T., Literature Search: K.B., Writing: M.K.Ç.

Conflict of Interest: No conflict of interest was declared by the authors.

Financial Disclosure: The authors declared that this study has received no financial support.

\section{References}

1. Papudesu C, Kottilil S, Bagchi S. Elbasvir/grazoprevir for treatment of chronic hepatitis C virus infection. Hepatol Int. 2016.

2. El Kassas M, Elbaz T, Abd El Latif Y, Esmat G. Elbasvir and grazoprevir for chronic hepatitis $C$ genotypes 1 and 4. Expert Rev Clin Pharmacol. 2016:1-9.

3. Rockstroh JK, Nelson M, Katlama C, Lalezari J, Mallolas J, Bloch M, Matthews GV, Saag MS, Zamor PJ, Orkin C, Gress J, Klopfer S, Shaughnessy M, Wahl J, Nguyen BY, Barr E, Platt HL, Robertson MN, Sulkowski M. Efficacy and safety of grazoprevir (MK-5172) and elbasvir (MK-8742) in patients with hepatitis C virus and HIV co-infection (C-EDGE CO-INFECTION): a non-randomised, openlabel trial. Lancet HIV. 2015;2:e319-327.

4. Sperl J, Horvath G, Halota W, Ruiz-Tapiador JA, Streinu-Cercel A, Jancoriene L, Werling K, Kileng H, Koklu S, Gerstoft J, Urbanek P, Flisiak R, Leiva R, Kazenaite E, Prinzing R, Patel S, Qiu J, AsanteAppiah E, Wahl J, Nguyen BY, Barr E, Platt HL. Efficacy and safety of elbasvir/grazoprevir and sofosbuvir/pegylated interferon/ ribavirin: A phase III randomized controlled trial. J Hepatol. 2016;65:1112-1119.

5. Lagging M, Brown A, Mantry PS, Ramii A, Weilert F, Vierling JM, Howe A, Gendrano IN, Hwang P, Zhang B, Wahl J, Robertson M, Mobashery N. Grazoprevir plus peginterferon and ribavirin in treatment-naive patients with hepatitis $\mathrm{C}$ virus genotype 1 infection: a randomized trial. J Viral Hepat. 2016;23:80-88. 